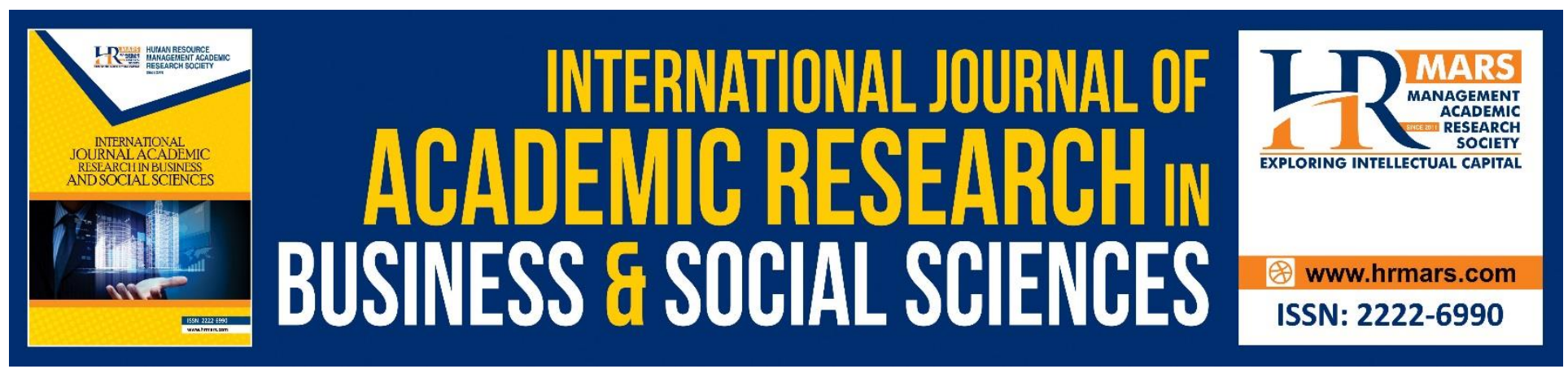

\title{
Feminine Movements of Seri Rama in Wayang Kulit Kelantan
}

\author{
Fara Dayana Mohd Jufry \\ Mohd Kipli Abdul Rahman
}

To Link this Article: http://dx.doi.org/10.6007/IJARBSS/v9-i2/5595

DOI: $\quad 10.6007 /$ IJARBSS/v9-i2/5595

Received: 22 Jan 2019, Revised: 16 Feb 2019, Accepted: 01 March 2019

Published Online: 04 March 2019

In-Text Citation: (Jufry \& Rahman, 2019)

To Cite this Article: Jufry, F. D. M., \& Rahman, M. K. A. (2019). Feminine Movements of Seri Rama in Wayang Kulit Kelantan. International Journal of Academic Research in Business and Social Sciences, 9(2), 617-631.

Copyright: (C) 2019 The Author(s)

Published by Human Resource Management Academic Research Society (www.hrmars.com)

This article is published under the Creative Commons Attribution (CC BY 4.0) license. Anyone may reproduce, distribute, translate and create derivative works of this article (for both commercial and non-commercial purposes), subject to full attribution to the original publication and authors. The full terms of this license may be seen at: http://creativecommons.org/licences/by/4.0/legalcode

Vol. 9, No. 2, 2019, Pg. 617 - 631

http://hrmars.com/index.php/pages/detail/IJARBSS

JOURNAL HOMEPAGE

Full Terms \& Conditions of access and use can be found at http://hrmars.com/index.php/pages/detail/publication-ethics 


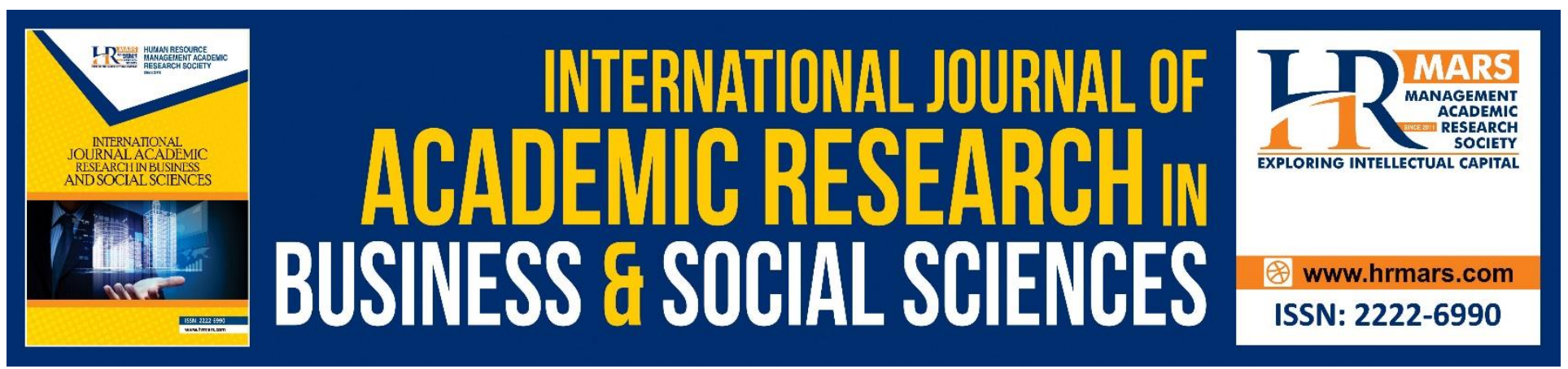

\title{
Feminine Movements of Seri Rama in Wayang Kulit Kelantan
}

\author{
Fara Dayana Mohd Jufry \\ Sultan Idris Education University \\ Email: faradayana@fmsp.upsi.edu.my \\ Mohd Kipli Abdul Rahman \\ Sultan Idris Education University \\ Email: kipli@fmsp.upsi.edu.my
}

\begin{abstract}
Seri Rama is a protagonist character in the repertoire of Hikayat Seri Rama which is performed in Wayang Kulit Kelantan. However, this protagonist character is a fine character that holds high feminine attributes. Therefore, to characterize these feminine attributes, gender schema theory is used as a reference by utilizing Bem Sex-Role Inventory as the quantifying measurement tool. There are three assessment techniques to analyze the feminine attributes, however this research analyses the feminine attributes of Seri Rama through the movements conducted by the dalang (puppeteer) during the performance. The movements of gambalan (puppets) have distinct differences between each gambalan and this shows that every characters has its own identity. These observed feminine attributes shows that a ruler like Seri Rama holds feminine traits.
\end{abstract}

Keywords: Wayang Kulit Kelantan, Gambalan, Feminine, Seri Rama

\section{Introduction}

Wayang Kulit Kelantan is a traditional theatrical performance that uses puppets to project shadows. The puppets used are known as gambalan by the performers in the early days. Gambalan is carved out and then performed by the dalang based on the repertoire of Wayang Kulit Kelantan (WKK) performance, which is Hikayat Seri Rama. The movements of the gambalan conducted by the dalang are based on fixed principles and passed down from generations. Apart from that, the movements of gambalan are bounded by the identity and personality of every characters. The identity of each characters is built up based on processes where this research utilizes Bem gender schema theory process as the guideline for identity building. Identity and personality of the characters can be observed through the movement of gambalan conducted by the dalang. 
Feminine movements of Seri Rama in WKK is characterized based on the story board that is observed across all the types of movements on the gambalan including body language and the transitional change of the placement of gambalan at the kelir. This is because every gambalan has its own identity and certain ways of movements. The movements of gambalan are divided into two, which are at the back and in front of kelir ${ }^{1}$. However, this research focuses on the shadows projected in front of kelir. The selection of this focus is because the shadow on the kelir is the end result produced in the process of gambalan movements.

\section{Gender Schema Theory}

This research uses Gender Schema Theory that was introduced by Sandra Lipsitz Bem as the guideline in data analysis process. The schema is a cognitive structure, a network of society and surrounding that place guidelines on individual perception (Bem, 1981). The schema is a mental representation of different traits, characters and actions related to women and men in a certain culture (Littlejohn \& Foss, 2009). Thus the schema is the result after the occurrence of internal interactions of an individual from psychological perspective before being translated into the form of actions or attitudes. These instances can been seen in the formation of identity for fine characters in WKK. On the other hand, gender schema theory is a phenomena resulted from sex-typing ${ }^{2}$, where part of it is based on gender, the readiness of public to process basic information related to gender that forms gender schema (Bem, 1981). Apart from that, Littlejohn and Foss (2009) also stated that gender schema theory is an individual perception seen based on the presence of information interaction and signs of assumption in the view of the present individual schema. Therefore, it is found that the formation of feminine traits in Seri Rama is shaped based on the background and self-development process parallel to his coming of age as a Tengku Mahkota of Sertapura Kingdom. Based on Bem, there are 20 schemas that portray feminine attributes as shown in Figure 1. However, this research breaks down only four feminine movements that presence in Seri Rama that made up as his self-identity.

${ }^{1}$ Kelir is a white screen that is use in the performance of Wayang Kulit Kelantan to project the shadow casted by gambalan.

2 Sex-typing refers to individual stereotype category based on looks or actions according to typical conventional perception genders. 
INTERNATIONAL JOURNAL OF ACADEMIC RESEARCH IN BUSINESS AND SOCIAL SCIENCES

Vol. 9, No. 2, Feb, 2019, E-ISSN: $2222-6990$ @ 2019 HRMARS

Items on the Masculinity, Femininity, and Social Desirability Scales of the BSRI

\begin{tabular}{lll}
\multicolumn{2}{c}{ Items on the Masculinity, Femininity, and Social Desirability Scales of the BSRI } \\
\hline \hline \multicolumn{1}{c}{ Masculine items } & \multicolumn{1}{c}{ Feminine items } & Neutral items \\
\hline 49. Acts as a leader & 11. Affectionate & 51. Adaptable \\
46. Aggressive & 5. Cheerful & 36. Conceited \\
58. Ambitious & 50. Childlike & 9. Conscientious \\
22. Analytical & 32. Compassionate & 60. Conventional \\
13. Assertive & 53. Does not use harsh language & 45. Friendly \\
10. Athletic & 35. Eager to soothe hurt feelings & 15. Happy \\
55. Competitive & 20. Feminine & 3. Helpful \\
4. Defends own beliefs & 14. Flatterable & 48. Inefficient \\
37. Dominant & 59. Gentle & 24. Jealous \\
19. Forceful & 47. Gullible & 39. Likable \\
25. Has leadership abilities & 56. Loves Children & 6. Moody \\
7. Independent & 17. Loyal & 21. Reliable \\
52. Individualistic & 26. Sensitive to the needs of others & 30. Secretive \\
31. Makcs desicions casily & 8. Shy & 33. Sincerc \\
40. Masculine & 38. Soft spoken & 42. Solemn \\
1. Self-reliant & 23. Sympathetic & 57. Tactful \\
34. Self-sufficient & 44. Tender & 12. Theatrical \\
16. Strong personality & 29. Understanding & 27. Truthful \\
43. Willing to take a stand & 41. Warm & 18. unpredictable \\
28. Willing to take risks & 2. Yielding & 54. Unsystematic \\
& &
\end{tabular}

Figure 1: Items on the Masculinity, Femininity, and Social Desirability Scales of the BSRI

Source: Bem (1974)

\section{Affectionate}

Affectionate is the first feminine attribute that can be identified through the movements of Seri Rama's gambalan. This affectionate attribute encompasses the love towards anyone including parents, spouse or people. For the character of Seri Rama, an example of feminine affectionate attribute can be seen between Seri Rama and other dignitaries in the kingdom of Sertapura. This can be seen when he calls out to all dignitaries to ask how well they are and ask if they are facing any problems that arise. Figure 2 shows the movement on kelir when Seri Rama displays the attribute of affection. 


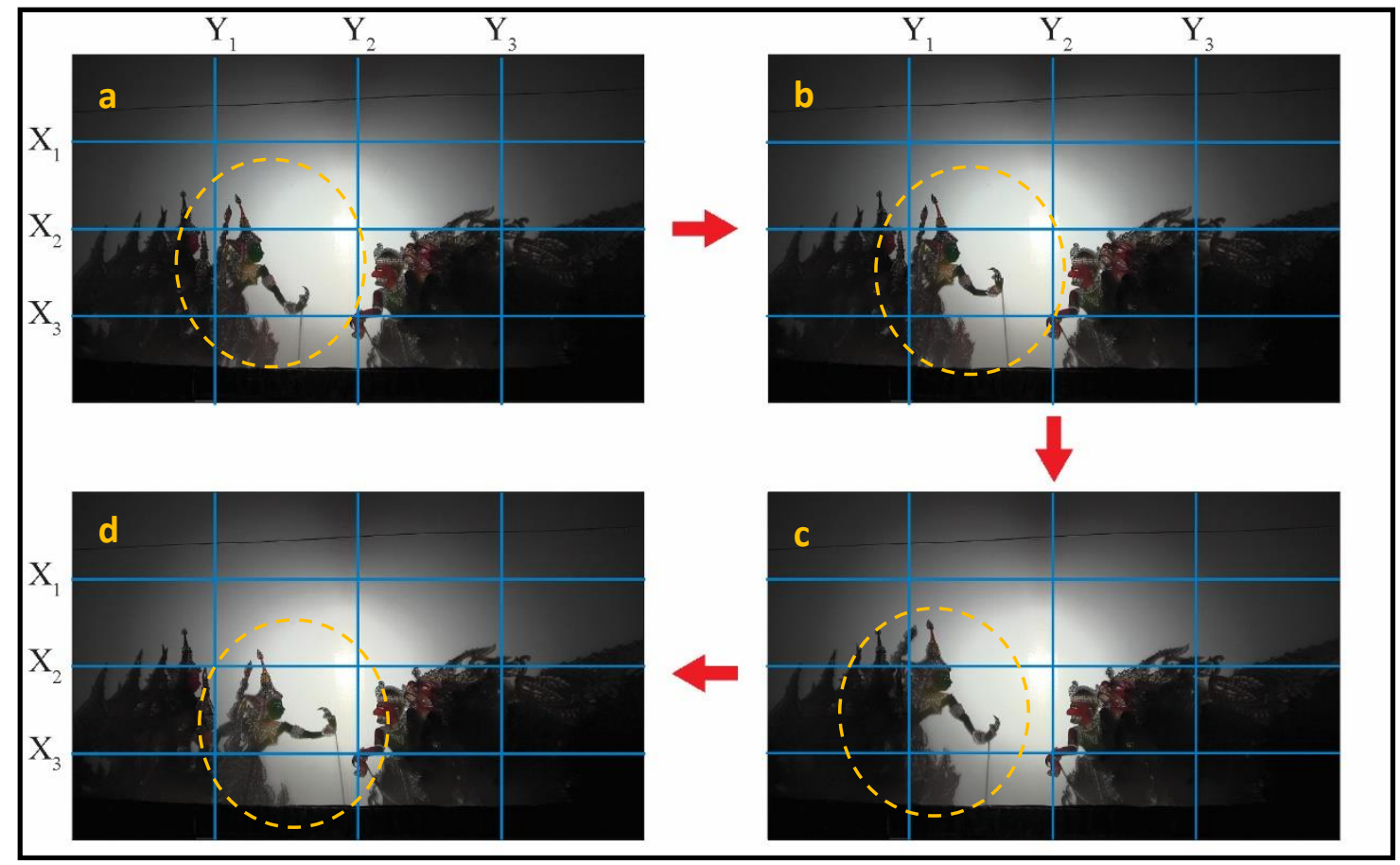

Figure 2: Affectionate attribute of Seri Rama through gambalan's movement Source: Fara Dayana Mohd Jufry (2018)

Based on the story board in figure 2, it is identified that Seri Rama's movements while discussing with other dignitaries of Sertapura kingdom is minimal. The movements of Seri Rama it this moment is limited to the movement of front hand and slight body movements. Affectionate is seen through the minimal movements of Seri Rama that shows his respects towards his kingdom's dignitaries. Apart from that, the tempo for the movements that happen also plays the role in confirming the feminine attributes of gambalan WKK. Figure 2a shows the hand of Seri Rama's position that starts on the $X_{3}$ line. At this moment, discussion begins with Seri Rama's hand moving from below.

The movement of Seri Rama's hand changes at figure $2 b$ with a slight move upwards forming a curve shape. Based on the discussion on previous chapter, curve line is a symbol of gentleness and the same concept is applied in the movement of gambalan. Thus, it can be seen in this figure, the warmth and connection between Seri Rama and the dignitaries around. Therefore, the attribute of affection is the result of the presence of gentleness and warmth between the connections among people.

In figure 2c, the front hand of Seri Rama moves downward and this shows that Seri Rama is uttering a speech. This is because it is identified that the speech by Seri Rama happens only when there is a movement of his front hand. Next in figure $2 d$, Seri Rama displays his firmness as a leader. However, this movement happens in a slow tempo depicting the identity of Seri Rama as a king. Seri Rama's movements are slow in order to display his noble status. Therefore the movements from 
figure $2 a$ until $2 c$ shows gentleness whereby figure $2 d$ shows firmness of Seri Rama despite the gentleness that he has to ensure his dignitaries are in good condition and is free from the issues in the kingdom. The impact of firmness from Seri Rama that is shown in this figure is reduced by lowering down the position of gambalan slightly lower than the previous figures. Moreover, even though his firm attribute is displayed in figure $2 d$, the affectionate attribute of Seri Rama is supported by the singing of tales song after the scene from above figure. Songs sung by the dalang through the character of Seri Rama is limited to certain characters to show that the dignitaries are special to Seri Rama.

\section{Childlike}

The second feminine attribute in the movements of Seri Rama is childlike. The age range of a child is the time where attention and love is needed the most from the parents. This attribute will reduce in parallel to the change of time and increments of age. However, when a child grows up, the attribute of needing attention stays as long as that individual holds feminine attributes deeper in them. This instance can be seen in figure 3 where the father of Seri Rama, Sirat Mahraja gives attention to Seri Rama.

Figure 3 starts with only two characters shown on the kelir, which are Seri Rama and his father, Sirat Mahraja. With Seri Rama being the long awaited child for Sirat Mahraja, the love and attention that is given to Seri Rama is different and comparable towards his three other children. Seri Rama is given the priority in all aspects including the governance of Sertapura kingdom. This can be seen in every scenes where in all the movements of Seri Rama and Laksamana, the dalang gives the priority to Seri Rama.

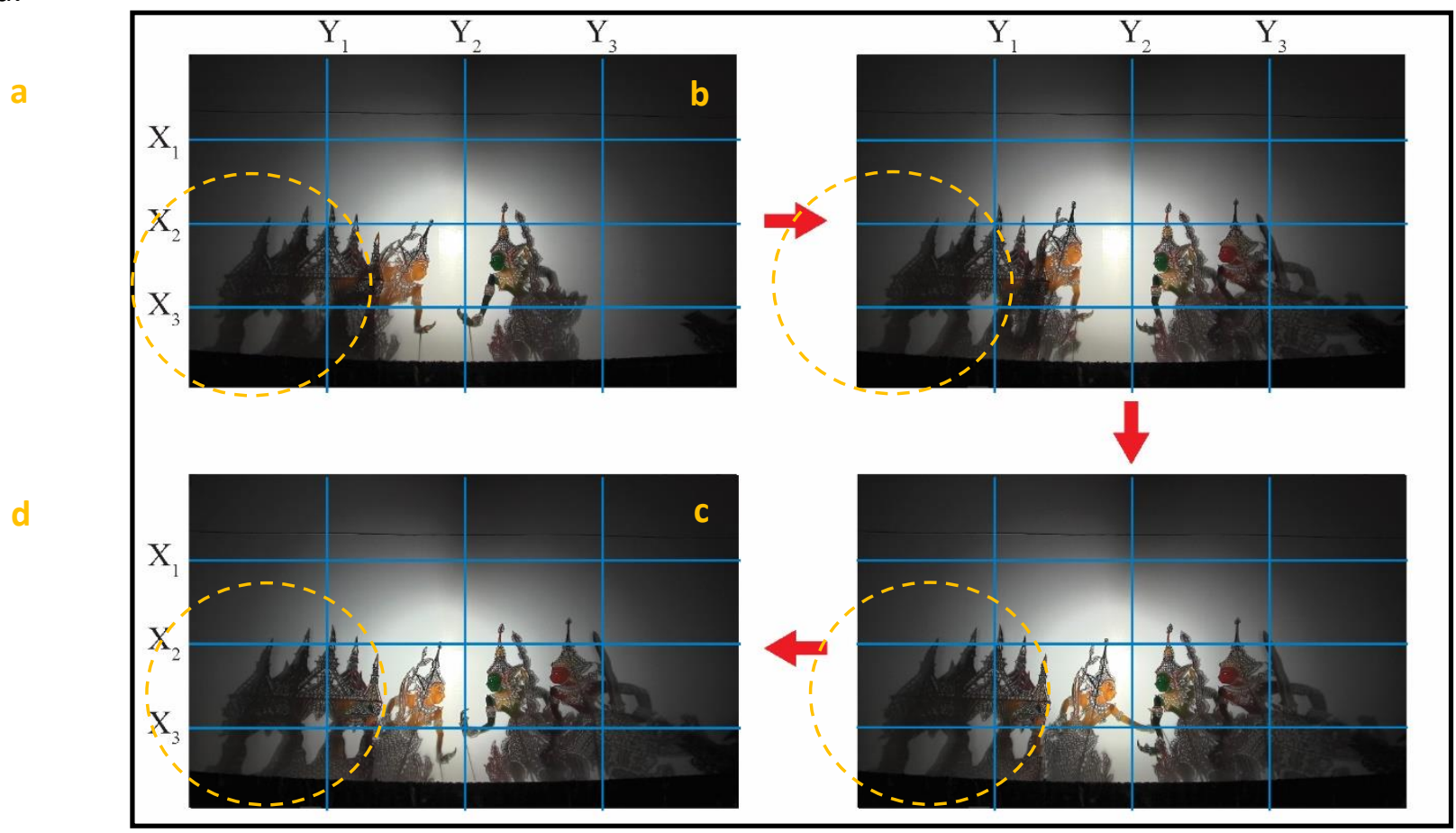

Figure 3: Seri Rama that is seen as childlike

Source: Jufry (2018) 
Figure 3a shows Sirat Mahraja is speaking and this can be seen with the gambalan slightly bows down showing that the dalang is holding the gambalan. At figure 3b, Seri Rama's gambalan is moved upfront to make space for positioning Laksamana's gambalan that comes in right after Seri Rama at the kelir. This change causes the distance between Seri Rama and his father becomes closer. Based on non-verbal communication concept, the distance in between individuals that are communicating shows the comfort level and connection between both. Therefore, the closer gap between this distances shows Seri Rama is more comfortable to be with Sirat Mahraja as compared to Laksamana that is positioned behind Seri Rama.

Next, figure 3c shows Seri Rama in a setting the he acts childlike where Sirat Mahraja gives all the attention to him and not to Laksamana. The attention is given by Sirat Mahraja through sense of touch in communicating. Figure $3 c$ displays Sirat Mahraja holding the hand of Seri Rama while instructing Seri Rama and Laksamana to seek out knowledge with a teacher by the name of Sahpian. Apart from that, the act of holding on to Seri Rama's hand by his father shows that Sirat Mahraja is heavy-hearted to let go of his son's hand but forced to. Seri Rama is being treated in this way since he is childlike, even though he is the older brother to Laksamana.

Seri Rama responded to the instruction given by Sirat Mahraja at figure $3 d$ is by moving his hand in curve form in the shape of semicircle. A circle or part of a circle symbolizes gentleness and this figure shows Seri Rama willingly obey to the instructions from his father. Clear attention is given by Sirat Mahraja to Seri Rama because the communication between Sirat Mahraja, Seri Rama and Laksamana is dominated by Seri Rama and their father. This shows that Seri Rama holds feminine attributes of childlike as he needs more attention from his father.

\section{Feminine}

Feminine attributes of Seri Rama can be identified in four situations. The first situation is when he exits the kelir by walking out. The way Seri Rama walks is based on the walking song which is exclusive to his character. Since the song is sung by the dalang when Seri Rama is walking, Seri Rama style of walking follows the tempo of the song until the song ends. Therefore, Seri Rama's walking song is played during entering kelir, walking at kelir and exiting the kelir. These movements is repeated until walking song for Seri Rama ends.

One of the movement that describes the identity of Seri Rama's feminine attribute is the kirat ${ }^{3}$ while exiting out of the kelir. This movement can be seen in figure 4. Figure 4a shows the final spot where Seri Rama walks before making the kirat to exit the kelir. At this moment, the position of Seri Rama is upright with the tip of his kecopong is on the $Y_{2}$ line. Figure $4 b$ shows the position where kirat is started by Seri Rama with gentle move based on the tempo of Seri Rama's walking song. The start of the kirat happens when Seri Rama's gambalan is pulled back to appear slanted to the front together with downright curve movement.

\footnotetext{
${ }^{3}$ Kirat is the term used by the performer of Kelantan traditional performance that refers to the movement of body twist in a certain style.
} 


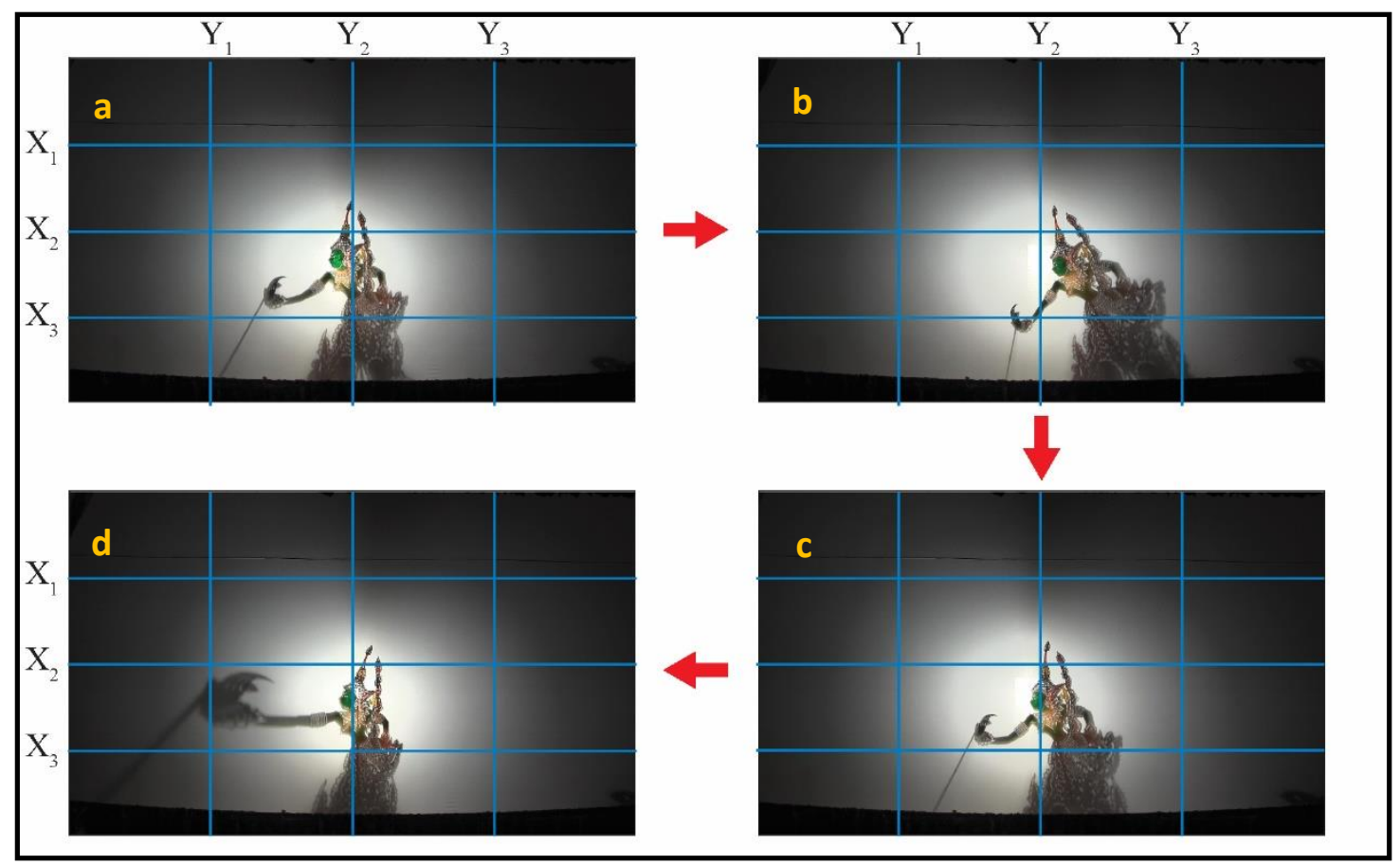

Figure 4: Kirat that displays feminine attribute of Seri Rama Source: Fara Dayana Mohd Jufry (2018)

Next, in figure 4c, once again Seri Rama is moved to the front to resemble the position in figure 4a. This movement also uses curve movement but different to the steps before. The curve movement on this second step is curved up. Finally, after the down curve and up curve completed, in summary, these movements complete a circular form. This circle shows the process of kirat has happened and Seri Rama exits in figure 4d. The circular shape resulted during kirat shows Seri Rama moves gently and holds his own esthetics. Apart from that, this circle shows that the movement is non-violent as compared to the movements for monsters tribe characters. Therefore, feminine attribute can be seen in this first situation.

Second situation that displays feminine characters of Seri Rama is when Seri Rama draws the arrow to shoot at the Tar tree. This situation also displays the feminine attribute of Seri Rama through the movements in curve forms. This can be seen and observed in detail in figure 5. Figure 5a shows Seri Rama at the right-hand side of the dalang ready to draw the arrow. The position at this moment makes it visible to see most of his body. The movement of gambalan that happens in figure $5 b$ shows the dalang moves Seri Rama's gambalan higher to get distance clearance to draw the arrow. The movement made by the dalang is in curve shape and from this position, Seri Rama's gambalan is moved again with a bigger curve than before. 


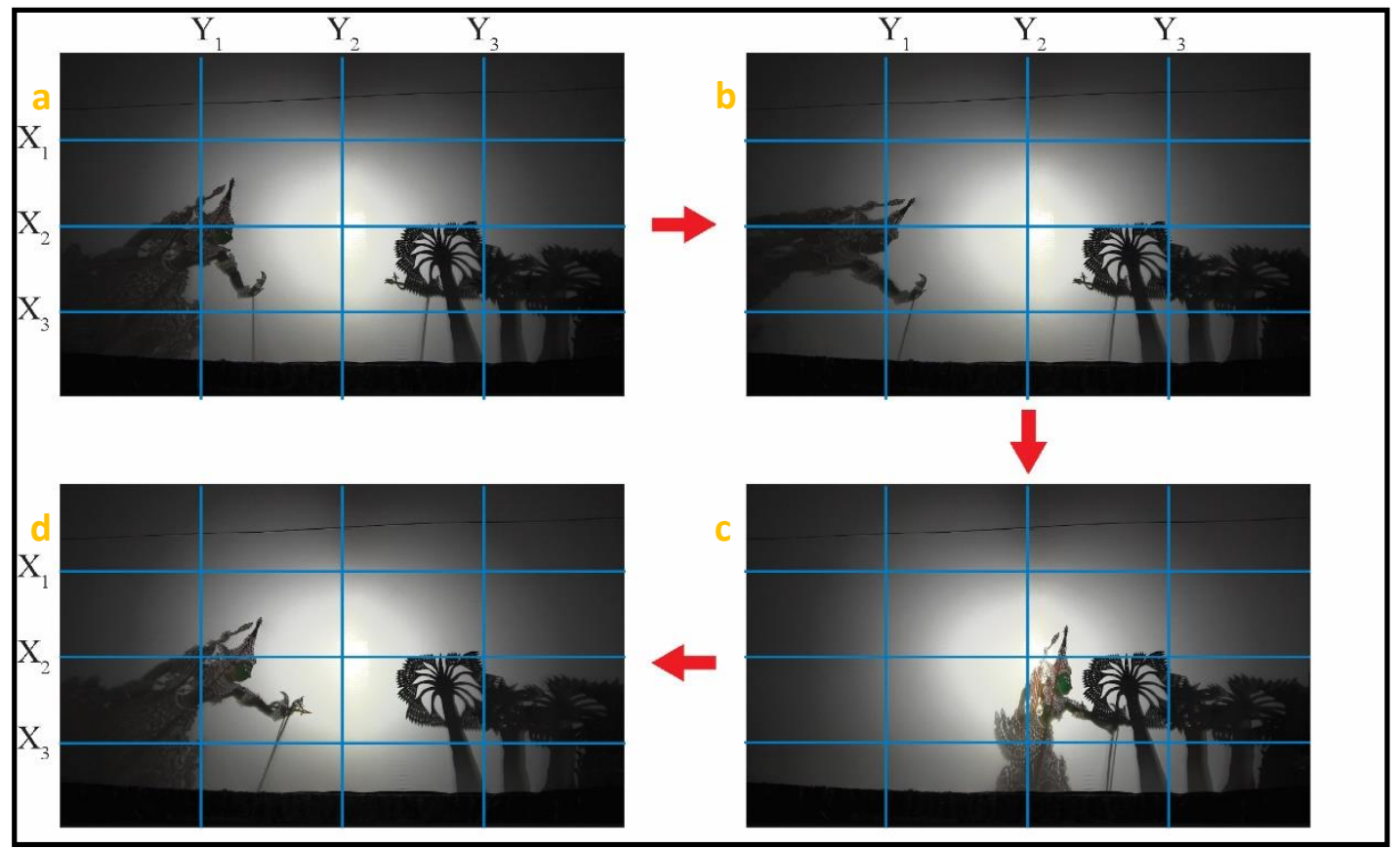

Figure 5: Seri Rama's movement of drawing an arrow Source: Fara Dayana Mohd Jufry (2018)

After drawing out the arrow in figure 5c, gambalan Seri Rama is once again moved to the back with a curve movement to be in the next position as shown in figure $5 \mathrm{~d}$. Therefore, every movement of Seri Rama in the figure above applies curve movement to maintain the identity of gentleness and feminine.

The next situation that displays feminine attribute of Seri Rama is when he seeks help from Laksamana after the first shot of arrow was a miss. This instance shows the attribute of Seri Rama that depends to others especially his brother, Laksamana. Even though he is a male, his attitude of depending on others is a feminine attribute the he holds in himself. 


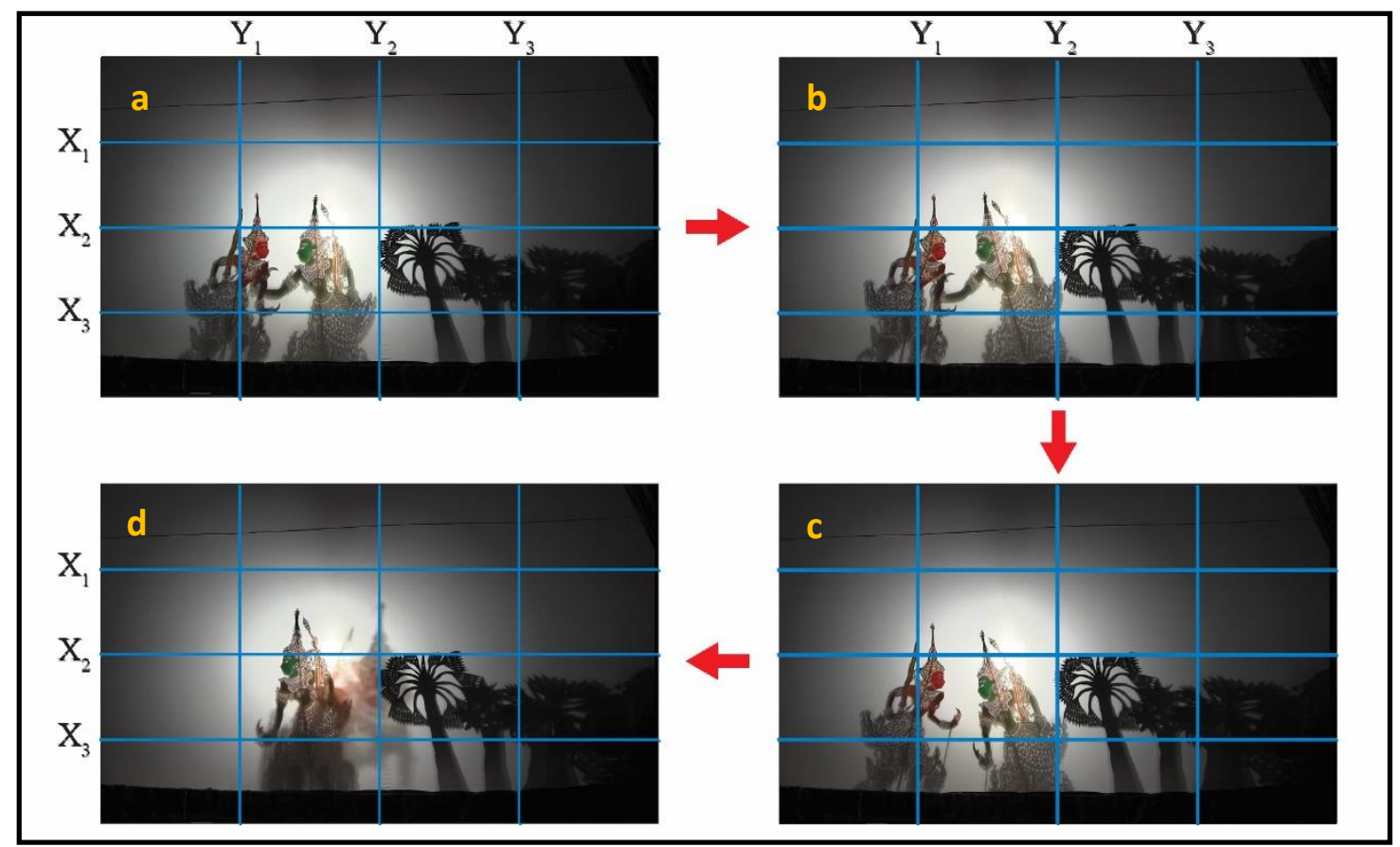

Figure 6: Seri Rama requesting help from Laksamana to shoot arrows at Tar tree Source: Fara Dayana Mohd Jufry (2018)

Figure 6 displays a serious discussion that happens between Seri Rama and Laksamana through the body movements of Seri Rama. This is because both of them were confused when the arrow being shot had missed all the Tar trees in a single shot. Therefore, Seri Rama requested the help of Laksamana to investigate the cause of the event. One of the identity of Seri Rama that can be identified through this situation is when he touched the body as a sign of closeness to seek help. This can be seen in figure 6a which shows Seri Rama holding the Laksamana's hand to seek his help to investigate the event. The touch that is made during communicating as an act that is frequently applied by women. Thus, the attribute of depending to others and by making physical touch during communicating confirms the feminine attribute of Seri Rama.

Figure $6 \mathrm{~b}$ shows Seri Rama moving slightly to the back but with his head slanted to make space and maintain comfortable distance between both of them. However, the touch to the part of Laksmana's hand still continues. The touch that is made by Seri Rama for quite a long moment displays that Seri Rama is really depending on his brother's help. With that, in figure $6 c$, the discussion gets more serious after Seri Rama stops touching the hand. Next in figure 6d, Laksamana who feels pity to his brother takes the move to help with the shooting of the Tar tree. In figure 6d, Seri Rama moves forward towards where his brother stands, and then Laksamana takes the responsibility to go to the back of the Tar tree to make observation.

Final situation that shows feminine attribute of Seri Rama is when once again seeks the help from Laksamana. The help that was requested shows that Seri Rama is incapable of being fully independent as a man should be and this can be seen in figure 7. Seri Rama requested the help from 
Laksamana when he was looking for Siti Dewi in Wat Tujuh Kedi Bermas where at that moment, Maharisi was not inside the Wat. Maharisi had left to send invites to his acquaintance to attend the wedding ceremony of his daughter, Siti Dewi. Since the departure of Maharisi had been 40 days, Seri Rama had decided not to wait for the return of Maharisi. Therefore, he went to search for Siti Dewi to be brought home to meet his father in Sertapura.

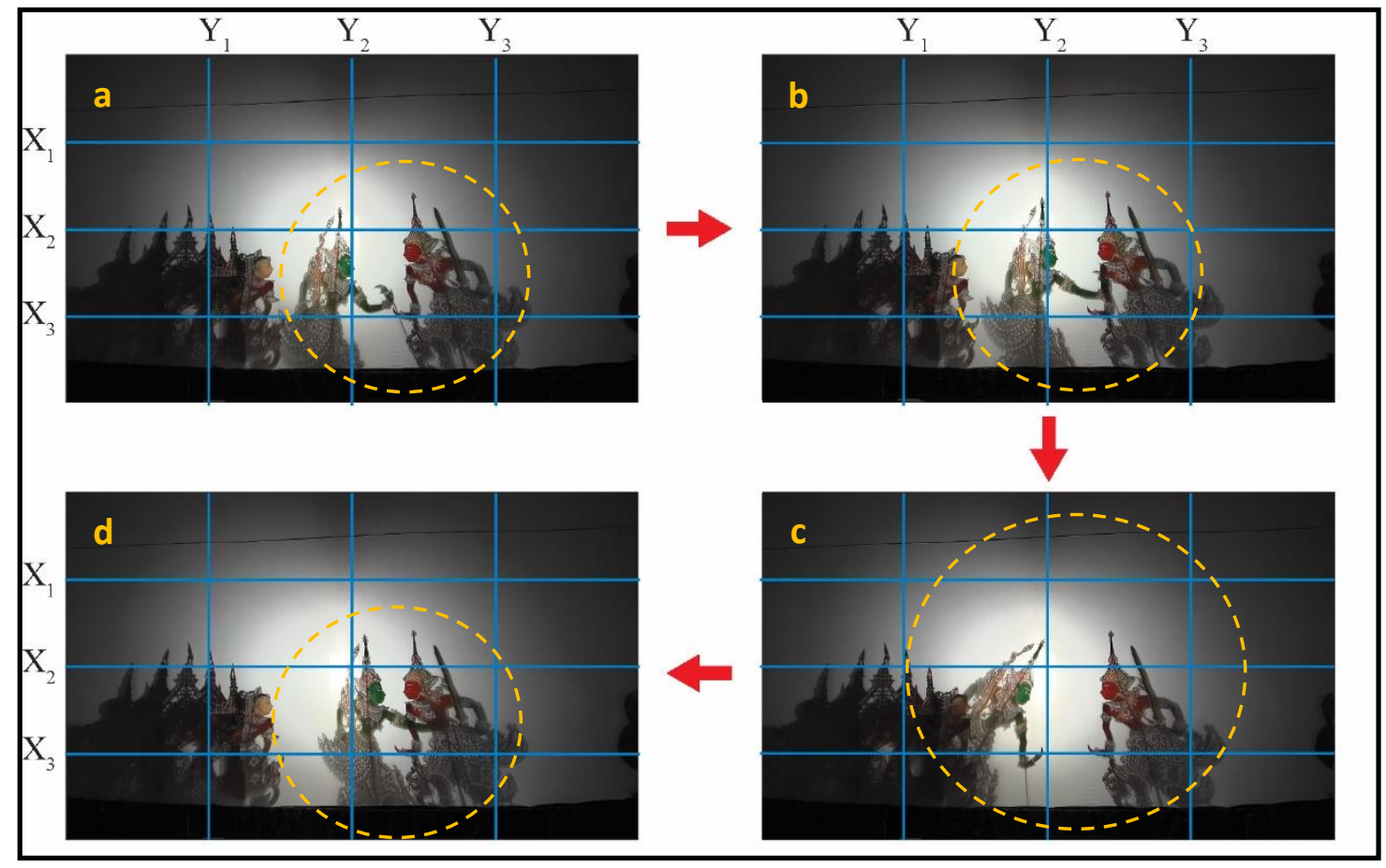

Figure 7: Ciri feminin Seri Rama ketika meminta bantuan Laksamana

Sumber: Fara Dayana Mohd Jufry (2018)

Figure 7a shows an event where Laksamana has just reached a location to meet his brother. Seri Rama had requested Laksamana's help to find Siti Dewi after he found there were 40 similar look-alike in the shape of statues. This is due to the fact that he is unable to think of the trick to identify the real Siti Dewi. This instance shows that Seri Rama has feminine attributes by asking the help from his brother. Therefore in figure 7a, Seri Rama speaks in a soft tone along with body movement at the front hand forming a curve. Curve shape symbolizes gentleness and this is the strategy used by Seri Rama to request for help. Next in figure 7b, once again Seri Rama uses physical touch to display closeness in order to get Laksamana to give help that he needs. However, Laksamana prohibited Seri Rama to do so in order to not betray the order given by Maharisi.

Figure 7c shows Seri Rama's gambalan being moved to the back with the head bowed down in a curve movement. The movement is made to display that the gentleness of Seri Rama at the second attempt is successful in getting the help from Laksamana. Therefore in figure 7d, Seri Rama tries to trigger the thoughts of his brother by positioning himself closer to Laksamana as compared to figure 7b. This position shows the tight-knit relation between both of them where Seri Rama touches the body of Laksamana as a sign of love. This make Laksamana feels divided and gives ideas 
and shares his thoughts to Seri Rama. Therefore, as seen in the final figure, feminine attributes of Seri Rama is clearly seen through the touch and seeking help from Laksamana.

\section{Gentle}

Gentle attributes that Seri Rama holds can be divided into two types, which are gentle movements that happens through the change of position and the movements that shows gentleness through his body movements. Figure 8 shows the movement of Seri Rama when walking with his brother while being sent out by Sirat Mahraja to seek knowledge. Sirat Mahraja had requested both of them to learn in order to equip them with more knowledge that can be applied during the ruling of the kingdom in the future after Sirat Mahraja passes the throne of Sertapura kingdom to Seri Rama.

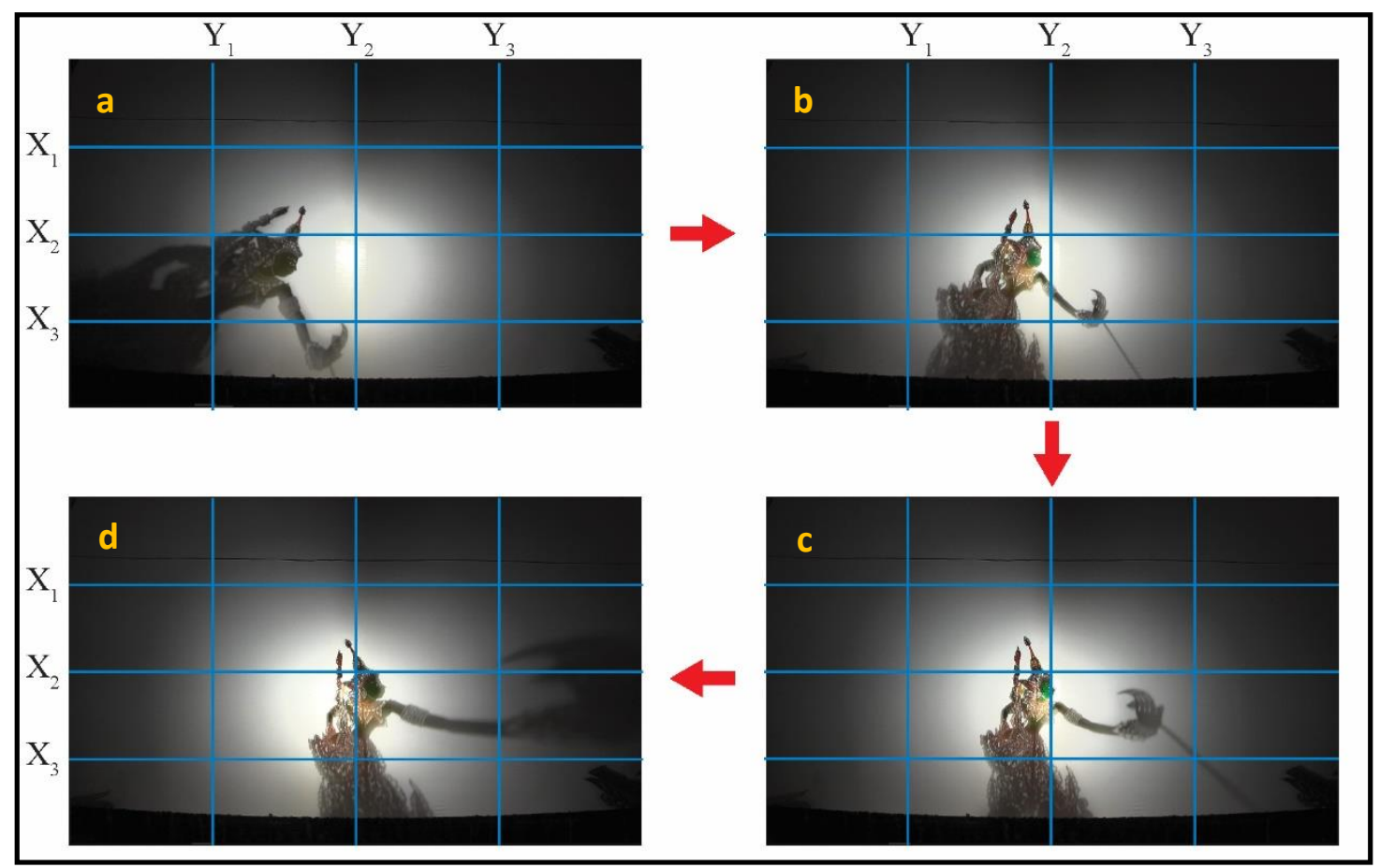

Figure 8: The gentle walk of Seri Rama

Source: Fara Dayana Mohd Jufry (2018)

Seri Rama's each footsteps when walking is based on a specific song that is played for him. This walking song starts with the dalang's singing and accompanied by music. Due to the nature of the song exclusive for a king, the tempo of this song is slow to portray the fine movements of Seri Rama. Figure 8a shows the shadow at the moment when Seri Rama's gambalan is entering the kelir area. Seri Rama's walking movements is started by the dalang from the right-hand side and not limited to only at kelir. Seri Rama is moved with the front hand forward starting from the side of dalang's shoulder. Figure 8 a shows the shadow projected is different in size as compared to the gambalan in figure $8 \mathrm{~b}, 8 \mathrm{c}$ and $8 \mathrm{~d}$. This is due to the variation of distance between the gambalan and the light bulb located behind the kelir. In figure $8 \mathrm{a}$, the distance between gambalan and light bulb is closer since the gambalan is not directly in contact with the kelir. Thus, the result is a bigger projected 
shadow. Apart from that, the movements that follows the tempo is a compulsory movements that the dalang has to follow. This compulsory step is a must, including the technique of holding the gambalan. These two steps are to be executed to ensure the style of walking for Seri Rama confirms to his identity and personality.

Seri Rama's gambalan that is in contact with part of the kelir around the head area can be seen in figure $8 b$ which is the first position when Seri Rama is moved to enter the kelir. Therefore, there is a significant movement disposition that happens from figure $8 \mathrm{a}$ to figure $8 \mathrm{~b}$. This movement happens in a slow manner based on the tempo of the song that is slow as well. This slow movement shows gentleness in the way Seri Rama walks. Apart from that, the movement from figure $8 a$ to $8 b$ is arranged by the dalang in a curve form to add gentleness in Seri Rama's movement. This curve begins from the dalang's shoulder and down to the kelir.

Figure 8c shows Seri Rama after walking and with intention of exiting the kelir. Seri Rama walks gently with a very small distance between each footsteps. Apart from the gentle movement, Seri Rama's footsteps is moved with small curve movements. After being moved with Seri Rama's movement technique, Seri Rama exits the kelir by taking the steps as shown in figure $8 \mathrm{c}$. This figure shows the dalang pulling Seri Rama's hand away from the clear and gets closer to the light bulb at the left side of dalang. Figure $8 \mathrm{~d}$ shows the movement of Seri Rama that is getting closer to the light bulb and projecting the shadow of the front hand to get bigger and blur. The exit movement out of the kelir also uses curve movements to maintain the identity of Seri Rama that is gently through the style of his walk.

The walking movement of Seri Rama can also be observed through the movement during the climb of a mountain when he wanted to study with the teacher named Sahpian. Figure 9 shows four positions of Seri Rama's gambalan before and during the mountain-climb. Figure 9 shows a Beringin tree at the right side of each caption. The beringin tree is the symbol of the mountain in the situation in this figure. 


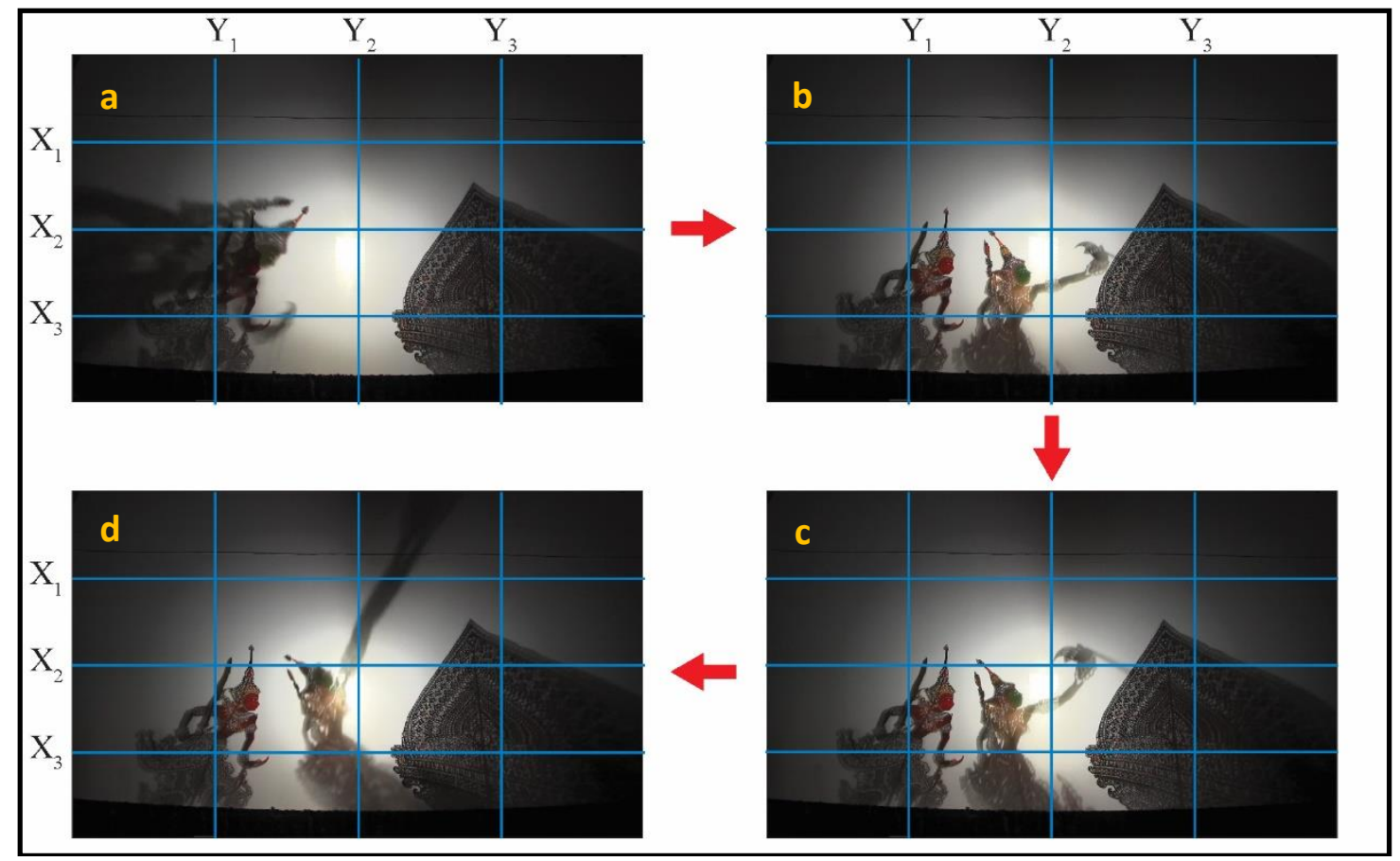

Figure 9: Seri Rama's movement of climbing a mountain Source: Fara Dayana Mohd Jufry (2018)

In figure 9a, the original position of Seri Rama is at the front of Laksamana and next, Seri Rama's gambalan is moved to the back of Laksamana. This movement in a curve is done simultaneously with moving the gambalan closer to the light bulb. This instance shows that Seri Rama is taking some clearance in order to move faster. This position displays the gentleness of Seri Rama with the movement in the form of a curve line. Seri Rama's gambalan moves again to the front as shown in figure $9 \mathrm{~b}$ which happens in a curve move as well. The gentle attribute of Seri Rama is once again can be seen from the movement in figure 9b and 9c when Seri Rama's movement is slowed down to almost a halt momentarily at this position. Only the music can be heard at that moment apart from the additional sound made by the dalang.

Finally in figure 9d, Seri Rama's gambalan is moved pointing upward as in the position of climbing the mountain. This position shows that Seri Rama is moving upward, preceded by his front hand that is starting to move away from kelir. Apart from that, this upward movement has significant meaning from philosophical perspective where not all individuals have the ability to move upwards with their own force.

Based on the analysis conducted, the identity and characteristic of Seri Rama is formed through a process that is influenced by surrounding communities. This identity that presences in Seri Rama can be seen by other individual through several aspects. One of the aspect that is studied is the movement of gambalan. Among four feminine attributes that can be identified in the movement of Seri Rama are affectionate, childlike, feminine and gentle. 
Moreover, this research is extendable by studying other aspects that reflect feminine attributes of Seri Rama. These aspects include the design form of the gambalan, design pattern of the gambalan and the dialog lines that is used by the dalang when playing the role of Seri Rama. This is in order to obtain feminine attributes of Seri Rama that is more comprehensive thus setting the identity guidelines of Seri Rama.

\section{REFFERENCES}

Bem, S. L. (1981). Gender Schema Theory: A Cognitive Account of Sex Typing. Psychological Review, 88(4), 354-364.

Bem, S. L. (1974). The Measurement Of Psychological Androgyny. Journal of Consulting and Clinical Psychology, 42(2), 155-162.

Stephen W. Littlejohn, \& Karen A. Foss. (2009). Encyclopedia of Communication Theory. In Brenda J. Allen, Charlotte Kroløkke, J. Kevin Barge, Mark P. Orbe, Roger de la Garde, James Taylor, Lisa A. Flores, Ingrid Volkmer, \& Vijai N. Giri (Eds.), Encyclopedia of Communication Theory. United States of America: Sage Publications, Inc. 